\title{
Nutrition in calcium nephrolithiasis
}

\author{
Elena Dogliotti ${ }^{1,2}$, Giuseppe Vezzoli ${ }^{3}$, Antonio Nouvenne ${ }^{4 *}$, Tiziana Meschi ${ }^{4}$, Annalisa Terranegra ${ }^{2}$, \\ Alessandra Mingione ${ }^{2}$, Caterina Brasacchio ${ }^{2}$, Benedetta Raspini ${ }^{2}$, Daniele Cusi ${ }^{2}$ and Laura Soldati ${ }^{2}$
}

\begin{abstract}
Idiopathic calcium nephrolithiasis is a multifactorial disease with a complex pathogenesis due to genetic and environmental factors. The importance of social and health effects of nephrolithiasis is further highlighted by the strong tendency to relapse of the disease. Long-term prospective studies show a peak of disease recurrence within 2-3 years since onset, $40-50 \%$ of patients have a recurrence after 5 years and more than $50-60 \%$ after 10 years. International nutritional studies demonstrated that nutritional habits are relevant in therapy and prevention approaches of nephrolithiasis. Water, right intake of calcium, low intake of sodium, high levels of urinary citrate are certainly important for the primary and secondary prevention of nephrolithiasis.

In this review is discussed how the correction of nutritional mistakes can reduce the incidence of recurrent nephrolithiasis.
\end{abstract}

Keywords: Nephrolithiasis, Nutrition, Calcium, Stones prevention

\section{Background}

Idiopathic nephrolithiasis is a disease that has been widely spread in countries with high socio-economic levels along with other conditions such as obesity, hypertension, atherosclerosis, cardiovascular disease and type 2 diabetes [1]. In these countries the prevalence of nephrolithiasis is about $6-9 \%$ in men and $3-4 \%$ in women $[2,3]$. Among the various types of stones, idiopathic calculi of calciumoxalate and/or calcium-phosphate are the most frequent form with a result of around 80\% [4-7]. The importance of social and health effects of nephrolithiasis is further highlighted by the strong tendency to relapse of the disease $[2,8-10]$. Long-term prospective studies show a peak of disease recurrence within 2-3 years since onset, 40$50 \%$ of patients have a recurrence after 5 years and more than $50-60 \%$ after 10 years [2]. The most affected are usually males $[11,12]$, but in recent decades the frequency of the disease is increasing, especially among women $[13,14]$ and today the sex ratio approaches unity [15]. The trend of prevalence is also increasing in developing countries such as China, India and Brazil in relation to changes in lifestyle [16]. It is believed that the calcium nephrolithiasis is a multifactorial disease of complex pathogenesis, whose

\footnotetext{
* Correspondence: antonio.nouvenne@alice.it

${ }^{4}$ Department of Clinical and Experimental Medicine, University of Parma, via A. Gramsci 14, 43126, Parma, Italy

Full list of author information is available at the end of the article
}

onset is due to multiple genetic and environmental factors [16-18].

The distribution of nephrolithiasis family does not prove a classic Mendelian transmission [19]. It is assumed, therefore, that multiple genes are involved, and their combination can produce in single individuals a specific predisposition to nephrolithiasis. However, genetic predisposition to nephrolithiasis can be modified by environmental factors, among which nutritional factors have an important role. These factors may modulate the lithogenic effects of gene products, but also change the same gene expression through specific mechanisms called "epigenetic". The discovery that the provision of specific nutrients can alter gene transcription has partly reversed the concepts of classical genetics giving a new and relevant importance to nutrients [20].

The analysis of dietary patterns has pointed out how the increased prevalence of stones in countries such as the United States went in parallel with the increased size of the portions consumed both at home and outside, along with the increased sedentary lifestyle and obesity, which has increased from $14.5 \%$ in 1971 to $30.9 \%$ in $1999[21,22]$. The same trend is observed in European northern countries, while in the countries of southern Europe there has been a gradual abandonment of the Mediterranean diet in the younger generations as well as their increased sedentary lifestyle and obesity [23].
C Biomed Central

(c) 2013 Dogliotti et al.; licensee BioMed Central Ltd. This is an Open Access article distributed under the terms of the Creative Commons Attribution License (http://creativecommons.org/licenses/by/2.0), which permits unrestricted use, distribution, and reproduction in any medium, provided the original work is properly cited. 
This review will take into account the nutritional aspects considered most peculiar in calcium nephrolithiasis.

\section{Nutritional factors}

\section{Water and other fluids}

Several studies $[14,24,25]$ have shown that people who consume a quantity of less than $1.5 \mathrm{~L} /$ day of fluids undergo kidney stones, accounting for $50 \%$ higher than people who assume more than $2.5 \mathrm{~L} /$ day of fluids [26]. Two studies, one observational [27] and one of intervention [28], demonstrate the beneficial effects of water intake, both on the prevention of kidney and on recurrences. As a result, it was observed that the relapse rate fell from $27 \%$ to $12 \%$, doubling from 1 to 2 L/day the volume of water daily consumed during a follow-up of 5 years.

If water is certainly important for the primary and secondary prevention of nephrolithiasis, it is still controversial whether the hard water with a high content of divalent ions, has the same anti-lithogenic effect of fresh water, with low dry residue [28]. The choice of the water to be consumed should be personalized, considering the overall contribution of trace elements such as calcium, sodium, potassium, chloride, magnesium and trace elements such as iron, fluorine, iodine, zinc, selenium. However, the choice of a oligomineral, low $\mathrm{NaCl}$ content water seems to offer a good compromise [29]. As an alternative to water, there are drinks that exert a positive effect since they increase $\mathrm{pH}$ and/or citrate and/or volume, such as for example freshly squeezed oranges or lemons, juices made from the same, green tea and wine [30].

Beer has been found to have a protective effect in calcium stone disease while it seems to increase the risk of urate stone disease due to the uricosuric effect caused by its high purine-guanosine content $[31,32]$. Cranberry juice is not known to protect from calcium nephrolithiasis but is particularly useful in cases of infected stone disease $[33,34]$.

Tea and coffee, on the other hand, increase oxalate even although it has been documented that this effect is cancelled out if milk is added, the calcium of which binds with the oxalate, thereby reducing its absorption [35]. Other drinks are pro-lithogenic, and have a mechanism which has not been fully understood (grapefruit and apple juice, cola) [36]. In this connection, it is important to mention soft drinks, given the quantities and frequency with which they are consumed: recent studies have identified an increased risk of both calcium and uric acid stone disease correlated with the consumption of soft drinks - probably due to their fructose, sucrose and phosphoric acid content - and have documented a reduction in the risk of recurrences of approx. 10\% in patients who were instructed to avoid soft drinks $[37,38]$.

\section{Calcium and sodium chloride}

Going from a dietary content of calcium equal to $400 \mathrm{mg} /$ day to one of $1200 \mathrm{mg} /$ day, urinary excretion of calcium increases from $120 \mathrm{mg} /$ day to $180 \mathrm{mg}$ /day in normal subjects and from $240 \mathrm{mg} /$ day to $400 \mathrm{mg} /$ day in hypercalciuric subjects $[29,39]$. For this reason, the reduction of the consumption of milk and dairy products has been for many years the first measure recommended to stone formers.

With the current knowledge [25,40] this requirement is unfounded for the following reasons: 1) the reduction of calcium in the diet increases the share of oxalate absorbed in the intestine because it prevents the formation of calcium-oxalate complexes which are not absorbable [41]; 2) when we recommend the dietary limitation of milk and dairy products, patients are likely to increase their animal protein intake in the form of meat, fish and poultry, leading to potential unfavorable consequences [29].

Many studies $[9,13,14,24]$ have shown that the risk of nephrolithiasis is lower than about 30\% during a diet with an intake of calcium around $1000 \mathrm{mg} /$ day compared to an intake of less than $600 \mathrm{mg} /$ day.

Furthermore, a randomized study conducted for 5 years on male hypercalciuric stone formers has demonstrated that a lower calcium content diet is less effective in the prevention of recurrences than a diet with a normal content of calcium, but with a low intake of salt and proteins [42].

A lot of studies have shown that the high consumption of cooking salt increases the excretion of calcium [10,42-44]. An increase of about $6 \mathrm{~g}(100 \mathrm{mmol})$ of $\mathrm{NaCl}$ generates an increase of calciuria of $40 \mathrm{mg}(1 \mathrm{mmol})$ in

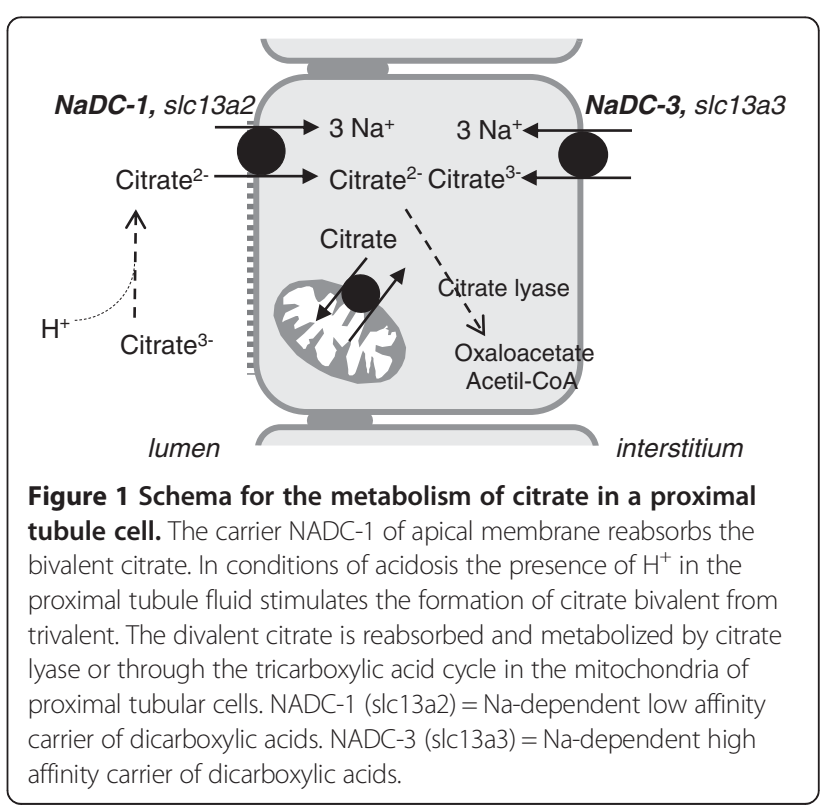


healthy adults and $80 \mathrm{mg}(2 \mathrm{mmol})$ in hypercalciuric subjects forming kidney stones $[29,43]$.

Several studies suggest that the calciuric effect of cooking salt is due to an inhibition of tubular reabsorption of calcium by the sodium and chloride and that this effect is additive to that of acid load promoted by proteins $[37,45,46]$, although a recent work has not confirmed these results [47]. The lithogenic risk is further increased by decreased excretion of citrate associated with the acid load and to cellular potassium deficiency [41-44].

\section{Citrate}

The urinary citrate is an inhibitor of the growth and aggregation of the crystals of calcium oxalate and calcium phosphate because it forms stable complexes with free calcium preventing the bond with oxalate and phosphate. This explains why one of the most common metabolic disorders associated with calcium nephrolithiasis is the hypocitraturia. Hypocitraturic patients have been described between 19 and $63 \%$ of stone formers in different statistics [48]. The measurement of citrate in the urine has been introduced into the metabolic routine of stone formers and its deficiency is correctable with an oral support of alkali in the majority of patients [48], even if one part of them does not normalize the excretion of citrate with the oral load of alkalis or citrate.

The main cause for hypocitraturia is metabolic acidosis, in its various forms. It works by promoting the formation of divalent citrate in the proximal renal tubule. The bivalent form is more easily reabsorbed in the proximal tubule (Figure 1) through a specific transporter (NADC-1) that is also expressed in the intestine (small intestine and colon). Moreover a NADC-1 defect has been associated to nephrolithiasis both in animals and humans [49-51]. The result of the acid load is therefore the decrease in urinary citrate.

Among the causative factors of hypocitraturia there is the low dietary consumption of fruit and vegetable. These foods increase the daily intake of alkalis that reduces the proportion of $\mathrm{H}^{+}$allowing the binding to the trivalent citrate and therefore reducing citrate tubular reabsorption [52]. A diet rich in fruits and vegetables is now part of the nutritional advices that are provided to patients not only for the effect on citraturia, but also because it helps to increase the volume of urine, provides alkaline potassium and magnesium, increases the urinary $\mathrm{pH}$ [53] and finally implies a lower content of animal protein and salt [46]. In 2010, Taylor and co-workers found that a DASH - style diet was associated with an increased urinary output, regardless of fluid intake [54]. They speculated that higher urinary volumes were a result of the higher food water content and they reported that a high dietary intake of fruits and vegetables was linked to increased urinary citrate levels and higher urine $\mathrm{pH}$. Several studies attribute the anti-lithogenic effect of vegetables to the mechanisms above listed.

\section{Conclusions}

An isolated episode of lithiasis in adulthood may be considered occasional. Many patients, however, keep on forming stones during their lives, with greater or lesser frequency. This can be associated only with the presence of stable predisposing factor, such as to cause a net increase in the risk of recurrence. In these situations, once solved any acute problem related to the presence of calculi in the urinary tract, the specialist must investigate the metabolic situation, in order to be able to provide detailed advice. However, we recall that the far more important role in preventing is that performed by dilution of urine with high introduction of liquids. We would also emphasize the importance of nutritional management of stone formers patients, through the introduction of a diet aimed to prevent or at least to delay recurrences. In fact, in these patients, who have a genetic background of increased lithogenic risk, it is possible that dietary mistakes can have more influence than in non-predisposed subjects.

\section{Abbreviations \\ NADC: Sodium dependent carrier; DASH diet: Dietary approaches to stop hypertension.}

\section{Competing interests}

The authors declare that they have no competing interests.

\section{Author's contributions}

$E D, G V, A N$, and LS have drafted the manuscript. TM, AT, AM, CB, BR, and DC have all contributed substantially to the manuscript. All authors have read and approved the final manuscript.

\section{Acknowledgements}

We thank Valentina Capone for English copyediting.

\section{Author details}

${ }^{1}$ Fondazione Umberto Veronesi, p.zza Velasca 5, 20142, Milano, Italy. ${ }^{2}$ Department of Health Sciences, Università degli Studi di Milano, via A. Di Rudini 8, 20142, Milano, Italy. ${ }^{3}$ Nephrology Unit, San Raffaele Hospital, via Olgettina 60, Milano, Italy. ${ }^{4}$ Department of Clinical and Experimental Medicine, University of Parma, via A. Gramsci 14, 43126, Parma, Italy.

Received: 5 February 2013 Accepted: 25 April 2013

Published: 1 May 2013

\section{References}

1. Racioppi M, Palermo G, D'Addessi A, Pinto F, Sacco E, D'Agostino D, Vittori M, Bassi PF: Hot topics in urological health economics. A mini review. Arch Ital Urol Androl 2012, 84(2):47-52.

2. Hughes P: The CARI guidelines. Kidney stones epidemiology. Caring for Australians with renal impairment (CARI). Nephrology (Carlton) 2007, 12(Suppl 1):S26-S30.

3. Worcester EM, Coe FL: Clinical practice. Calcium kidney stones. N Engl J Med 2010, 363(10):954-963

4. Soucie JM, et al: Demographic and geographic variability of kidney stones in the United States. Kidney Int 1994, 46(3):893-899.

5. Goldfarb DS: Increasing prevalence of kidney stones in the United States. Kidney Int 2003, 63:1951-1952.

6. Borghi L, et al: Epidemiological aspects of nefrolithiasis. G It Met Min 1989, 3(2):71-79. 
7. Evan P: Physiopathology and etiology of stone formation in the kidney and the urinary tract. Pediatr Nephrol 2010, 25(5):831-841.

8. Trinchieri A, Coppi F, Montanari E, Del Nero A, Zanetti G, Pisani E: Increase in the prevalence of symptomatic upper urinary tract stones during the last ten years. Eur Urol 2000, 37:23-25.

9. Curhan GC, Willett WC, Rimm EB, Stampfer MJ: A prospective study of dietary calcium and other nutrients and the risk of symptomatic kidney stones. N Engl J Med 1993, 328:833-838.

10. Asplin JR, Coe FL, Favus MJ: Nefrolitiasis, in Harrison - principles of internal medicine $16^{a}$ ed. McGraw-Hill 2005, 268:1927-1932

11. Thomas M: The CARI guidelines. Clinical diagnosis of kidney stones. Caring for Australians with renal impairment (CARI). Nephrology (Carlton) 2007, 12(Suppl 1):S1-S3.

12. Semins MJ, Shore AD, Makary MA, Magnuson T, Johns R, Matlaga BR: The association of increasing body mass index and kidney stone disease. J Urol 2010, 183:571-575.

13. Yi JJ, Yi $L$, Xiang GZ, Qing $W W$, Yong $L$, Jiang $L J$, Semins $M J$, Shore $A D$, Makary MA, Magnuson T, Johns R, Matlaga BR: Re: the association of increasing body mass index and kidney stone disease. J Urol 2010, 183:571-575. J Urol. 2011 May; 185(5): 1984.

14. Curhan GC, Willett WC, Speizer FE, Spiegelman D, Stampfer MJ: Comparison of dietary calcium with supplemental calcium and other nutrients as factors affecting the risk for kidney stones in women. Ann Intern Med 1997, 126:497-504

15. Curhan GC, Willett WC, Knight EL, Stampfer MJ: Dietary factors and the risk of incidence kidney stones in younger women. Arch Intern Med 2004, 164:885-891.

16. Daudon M, Bounxouei B, Santa Cruz F, Leite Da Silva S, Diouf B, Angwafoo FF 3rd, Talati J, Desrez G: Composition of renal stones currently observed in non -industrialized countries. [Article in French] Prog Urol 2004, 14(6):1151-1161

17. Scales CD Jr, Curtis LH, Norris RD, Springhart WP, Sur RL, Schulman KA, Preminger GM: Changing gender prevalence of stone disease. J Urol 2007, 177(3):979-982.

18. Sakhaee K, Maalouf NM, Sinnott B: Kidney stones 2012: pathogenesis, Diagnosis and Management. J Clin Endocrinol Metab 2012, 97:1847-1860.

19. Miller NL, et al: Pathogenesis of renal calculi. Urol Clin North Am 2007, 34(3):295-313.

20. Phillips CM: Nutrigenetics and metabolic disease: current status and implications for personalised nutrition. Nutrients 2013, 5(1):32-57.

21. Kant AK, Graubard Bl: Secular trends in patterns of self-reported food consumption of adult Americans: NHANES 1971-1975 to NHANES 1999-2002. Am J Clin Nutr 2006, 84(5):1215-1223.

22. Jolliffe D: Extent of overweight among US children and adolescents from 1971 to 2000. Int J Obes Relat Metab Disord 2004, 28(1):4-9.

23. Vezzoli G, Terranegra A, Arcidiacono T, Soldati L: Genetics and calcium nephrolithiasis. Kidney Int 2011, 80(6):587-593.

24. Lopez M, Hoppe B: History, epidemiology and regional diversities of urolithiasis. Pediatr Nephrol 2010, 25(1):49-59.

25. Taylor EN, Stampfer MJ, Curhan GC: Dietary factors and the risk of incident kidney stones in men: new insight after 14 years of follow -up. J Am Soc Nephrol 2004, 15:3225-3232.

26. Kairaitis $L$ : The CARI guidelines. Kidney stones: prevention of recurrent calcium nephrolithiasis. Caring for Australians with renal impairment (CARI). Nephrology (Carlton) 2007, 12(Suppl 1):S11-S20.

27. Frank M, De Vries A, Tikva P: Prevention of urolithiasis. Arch Environ Health 1966, 13:625-630

28. Borghi L, Meschi T, Amato F, Briganti A, Novarini A, Giannini A: Urinary volume, water recurrences in idiopatic calcium nephrolitiasis: a 5 year randomized prospective study. J Urol 1996, 155:839-884.

29. Nouvenne A, Meschi T, Guerra A, Allegri F, Prati B, Borghi L: Dietary treatment of nephrolithiasis. Clin cases Miner Bone Metab 2008, 5(2):135-141.

30. Meschi T, Nouvenne A, Borghi L: Lifestyle recommendations to reduce the risk of kidney stones. Urol Clin North Am 2011, 38(3):313-320.

31. Jeong BC, Kim BS, Kim Jl, et al: Effects of green tea on urinary stone formation: an in vivo and in vitro study. J Endourol 2006, 20:356-361.

32. Johri N, Cooper B, Robertson W, et al: An update and practical guide to renal stone management. Nephron Clin Pract 2010, 116:159-171.

33. Kessler $T$, Jansen $B$, Hesse A: Effect of blackcurrant-, cranberry-, and plum juice consumption on risk factors associated with kidney stones formation. Eur J Clin Nutr 2002, 56(10):1020-1023.
34. Jepson RG, Williams G, Craig JC: Cranberries for preventing urinary tract infections. Cochrane Database Syst Rev 2012, 10:CD001321.

35. Savage GP, Charrier MJ, Vanhanen L: Bioavailability of soluble oxalate from tea and the effect of consuming milk with the tea. Eur J Clin Nutr 2003, 57(3):415-419.

36. Curhan GC, Willett WC, Rimm EB, Spiegelman D, Stampfer MJ: Prospective study of beverage use and the risk of kidney stones. Am J Epidemiol 1996, 143(3):240-247.

37. Fink HA, Akornor JW, Garimella PS, et al: Diet, fluid, or supplements for secondary prevention of nephrolithiasis: a systematic review and metaanalysis of randomized trials. Eur Urol 2009, 56:72-80.

38. Rodgers A: Effect of cola consumption on urinary biochemical and physicochemical risk factors associated with calcium oxalate urolithiasis. Urol Res 1999, 27:77-81.

39. Lemann J Jr, Adams ND, Gray RW: Urinary calcium excretion in human beings. N Engl J Med 1979, 30:535-541.

40. Coe FL, Parks JH, Asplin JR: The pathogenesis and treatment of kidney stones. N Engl J Med 1992, 327:1141-1152.

41. Lehmann J Jr, Pleuss JA, Gray RW: Increased dietary calcium intakes reduce urinary oxalate excretion in healthy adults. In Urolithiasis. Edited by Walzer VR, Sutton RAL, Cameron ECB, Pak CYC, Robertson WG. New York and London: Plenum Press; 1989:435-438.

42. Borghi L, Schianchi T, Meschi T, et al: Comparison of two diets for the prevention of recurrent stones in idiopathic hypercalciuria. N Engl J Med 2002, 346:77-84

43. Massey LK, Whiting SJ: Dietary salt, urinary calcium and kidney stone risk. Nutr Rev 1995, 53:131-134.

44. Nouvenne A, Meschi T, Prati B, Guerra A, Allegri F, Vezzoli G, Soldati L, et al: Effects of a low-salt diet on idiopathic hypercalciuria in calcium-oxalate stone formers: a 3-mo randomized controlled trial. Am J Clin Nutr 2010, 91:565-570.

45. Colussi G, Surian M, De Ferrari ME, Pontoriero G, Rombolà G, Brando B, Malberti F, Cosci P, Aroldi A, Castelnovo C: Relationship between sodium intake, proximal tubular function and calcium excretion in normal subjects and in idiopathic hypercalciuria. Eur Proc Eur Dial Transplant Assoc 1983, 20:455-459.

46. Meschi T, Nouvenne A, Ticinesi A, Prati B, Guerra A, Allegri F, Pigna L, Soldati $L$, et al: Dietary habits in women with recurrent idiopathic calcium nephrolithiasis. J Trans/ Med 2012, 10:63-70.

47. Maalouf NM, Moe OW, Adams-Huet B, Sakhaee K: Hypercalciuria associated with high dietary protein intake is Not Due to acid load. $J$ Clin Endocrinol Metab 2011, 96:3733-3740.

48. Caudarella R, Vescini F: Urinary citrate and renal stone disease: the preventive role of alkali citrate treatment. Arch Ital Urol Androl 2009, 81(3):182-187

49. He Y, Chen X, Yu Z, Wu D, Lv Y, Shi S, Zhu H: Sodium dicarboxylate cotransporter-1 expression in renal tissues and its role in rat experimental nephrolithiasis. J Nephrol 2004, 17(1):34-42.

50. Okamoto N, Aruga S, Matsuzaki S, Takahashi S, Matsushita K, Kitamura T: Associations between renal sodium-citrate cotransporter ( $\mathrm{hNaDC}-1)$ gene polymorphism and urinary citrate excretion in recurrent renal calcium stone formers and normal controls. Int J Urol 2007, 14(4):344-349.

51. Strohmaier WL, Seilnacht J, Schubert G: Urinary stone formers with hypocitraturia and 'normal' urinary $\mathrm{pH}$ are at high risk for recurrence. Urol Int 2012, 88(3):294-297.

52. Reddy ST, Wang CY, Sakhaee K, Brinkley L, Pak CYC: Effect of lowcarbohydrate high protein diets on acid-base balance, stone forming propensity, and calcium metabolism. Am J Kidney Dis 2002, 40:265-274

53. Zuckerman J, Assimos DG: Hypocitraturia: pathophysiology and medical management. Rev Urol 2009, 11(3):134-144.

54. Taylor EN, Fung TT, Curhan GC: DASH-style diet associates with reduced risk for kidney stones. J Am Soc Nephrol 2009, 20(10):2253-2259.

doi:10.1186/1479-5876-11-109

Cite this article as: Dogliotti et al: Nutrition in calcium nephrolithiasis.

Journal of Translational Medicine 2013 11:109. 